\title{
Ticks are more suitable than red foxes for monitoring zoonotic tick-borne pathogens in northeastern Italy
}

\author{
Graziana Da Rold', Silvia Ravagnan', Fabio Soppelsa², Elena Porcellato', Mauro Soppelsa², Federica Obber ${ }^{1}$, \\ Carlo Vittorio Citterio ${ }^{1}$, Sara Carlin ${ }^{1}$, Patrizia Danesi ${ }^{1}$, Fabrizio Montarsi ${ }^{1}$ and Gioia Capelli ${ }^{\text {** }}$
}

\begin{abstract}
Background: Northeastern Italy is a hotspot for several tick-borne pathogens, transmitted to animals and humans mainly by lxodes ricinus. Here we compare the results of molecular monitoring of ticks and zoonotic TBPs over a six-year period, with the monitoring of red foxes (Vulpes vulpes) in an endemic area.

Results: In the period 2011-2016, 2,578 ticks were collected in 38 sites of 20 municipalities of Belluno Province. Individual adults (264), pooled larvae $(n=330)$ and nymphs $(n=1984)$ were screened for tick-borne encephalitis virus, Borrelia burgdorferi (s.l.), Rickettsia spp., Babesia spp., Anaplasma phagocytophilum and "Candidatus Neoehrlichia mikurensis" by specific SYBR green real-time PCR assays and sequencing. The spleens of $97 \mathrm{foxes}$, culled in the period 2015-2017 during sport hunting or population control programs, were also screened. Overall, nine different pathogens were found in I. ricinus nymph and adult ticks: Rickettsia helvetica (3.69\%); R. monacensis (0.49\%); four species of the B. burgdorferi (s.l.) complex [B. afzelii (1.51\%); B. burgdorferi (s.s.) (1.25\%); B. garinii (0.18\%); and B. valaisiana (0.18\%)]; A. phagocytophilum (3.29\%); "Candidatus N. mikurensis" (1.73\%); and Babesia venatorum (0.04\%). Larvae were collected and screened in the first year only and two pools (0.6\%) were positive for $R$. helvetica. Tick-borne encephalitis virus was not found in ticks although human cases do occur in the area. The rate of infection in ticks varied widely according to tick developmental stage, site and year of collection. As expected, adults were the most infected, with $27.6 \%$ harboring at least one pathogen compared to $7.3 \%$ of nymphs. Pathogens with a minimum infection rate above $1 \%$ were recorded every year. None of the pathogens found in ticks were detectable in the foxes, 52 (54\%) of which were instead positive for Babesia cf. microti (also referred to as Babesia microti-like, "Theileria annae", "Babesia annae" and "Babesia vulpes").
\end{abstract}

Conclusions: The results show that foxes cannot be used as sentinel animals to monitor tick-borne pathogens in the specific epidemiological context of northeastern Italy. The high prevalence of Babesia cf. microti in foxes and its absence in ticks strongly suggests that I. ricinus is not the vector of this pathogen.

Keywords: Tick-borne pathogens, Ixodes ricinus, Red fox, Zoonosis, Monitoring

\section{Background}

The territory of northeastern Italy is occupied mainly by Alpine and pre-Alpine areas, characterized by a wellconserved biocenosis including rodents, carnivores, deer, wild boars and birds. The humid climate and availability of hosts provide favorable conditions for the proliferation of Ixodes ricinus, the most abundant tick in the area

\footnotetext{
* Correspondence: gcapelli@izsvenezie.it

${ }^{1}$ Istituto Zooprofilattico Sperimentale delle Venezie, Legnaro, Italy

Full list of author information is available at the end of the article
}

[1], and for the survival and maintenance of tick-borne pathogen (TBP) life-cycles.

The TBP Borrelia burgdorferi was first isolated from $I$. ricinus in northeastern Italy in 1989 [2]. Several other pathogens were later discovered in $I$. ricinus questing ticks, i.e. B. afzelii, B. garinii, B. burgdorferi (s.s.), B. valaisiana, B. lusitaniae, Rickettsia helvetica, $R$. monacensis, $R$. raoultii, $R$. limoniae, "Candidatus Neoehrlichia mikurensis", Anaplasma phagocytophilum, tick-borne encephalitis flavivirus, Babesia venatorum, Ba. capreoli 
and $\mathrm{Ba}$. microti-like $[1,3-20]$. The northeast also accounts for the majority of human cases of Lyme borreliosis and tick-borne encephalitis in Italy [21].

In the area of our survey, Belluno Province, the first European sequence of the bacterium (later suggested to be "Ca. N. mikurensis") was found in I. ricinus detached from humans [22, 23] and then in questing ticks $[24,25]$.

As a result, surveillance programmes for tick-borne infections have been implemented locally, often following the upsurge of human cases. They generally aim to (i) assess the infection rate in ticks; (ii) monitor variations of pathogen prevalence; and (iii) detect the introduction of any new pathogens or vectors. The programmes are mainly based on the collection and molecular screening of $I$. ricinus ticks, along with occasional serological surveys on domestic animals or forestry workers [26]. The collection of ticks and their molecular screening is, however, time-consuming and costly. For example, the costs for a survey conducted during 2006-2008 in northeastern Italy, including travel expenses, staff, molecular analysis and sequencing, was estimated at over $€ 20,000$ per year [19].

Alternatively, wild mammals that host I. ricinus ticks and are susceptible to TBPs may be used as sentinels. The survey area hosts 42 mammalian species including deer (chamois, red deer, roe deer, mouflon), bats, foxes, marmots, badgers, stoats, martens, squirrels, lynxes, wolves, in addition to bears and, since 2014, wildcats [27]. The red fox (Vulpes vulpes) could be a good candidate for surveillance since it is widespread, abundant [28], and subject to sport hunting and possible population control plans. In previous studies, blood or spleen samples from red foxes were found positive for TBPs transmitted by Ixodes spp. such as A. phagocytophilum, with a prevalence ranging between $0.6-16.6 \%$ in Italy [29] and other European countries [30-33], and B. burgdorferi, found in $1.42 \%$ of foxes in Romania [31].

Being the main reservoir of important zoonotic pathogens (Trichinella britovi, Echinococcus multilocularis, rabies virus), surveillance programs on red foxes are already in place in our study area, making sampling easier and more cost-effective.

The aim of this study was to assess the suitability of red foxes, assigned to Istituto Zooprofilattico Sperimentale delle Venezie, as sentinel animals for zoonotic TBPs, with the molecular screening of I. ricinus, in northeastern Italy.

\section{Methods}

\section{Study area and sampling}

Between 2011 and 2016, ticks were collected by forest rangers and local health unit personnel, by standard dragging using a $1 \mathrm{~m}^{2}$ white flannel cloth. Sampling was performed monthly in five sites during the peak of Ixodes spp. activity, i.e. in spring (April, May and June) and autumn (September and October), based on previous experience in northeastern Italy [19, 34]. A further 33 sites were visited only sporadically, from one to three times. The altitude of the sampling sites ranged from 340 to 1,792 meters above sea level (masl).

All 38 sampling sites were located in 20 municipalities within the Dolomiti Bellunesi National Park in the Province of Belluno $\left(3600 \mathrm{~km}^{2}\right)$, an area of the Veneto Region neighboring the Friuli Venezia Giulia and Trentino Alto Adige regions (Italy), and Austria (Fig. 1). The climate is

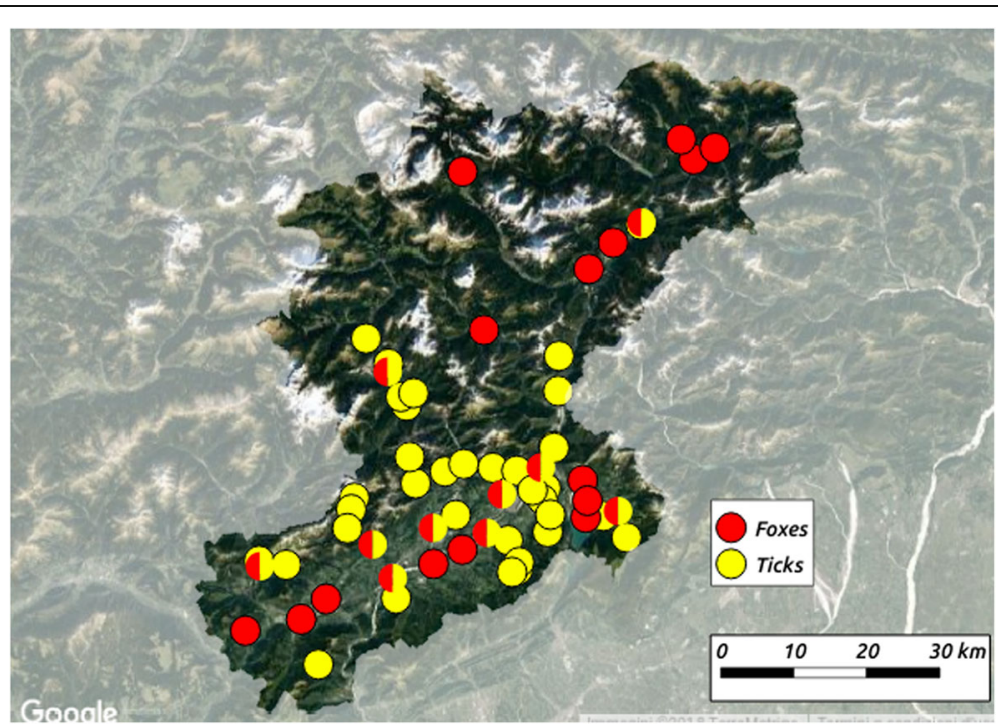

Fig. 1 Municipalities where Ixodes ricinus ticks and red foxes (Vulpes vulpes) were sampled in the Belluno Province, northeastern Italy. Mixed circles (yellow/red) represent municipalities where both ticks and foxes were sampled 
sub-continental, with cold and often snowy winters and mild, warm summers. Belluno Province is humid, rich in water, and crossed by the wide Piave River. The average annual temperature is $9{ }^{\circ} \mathrm{C}$, and the average annual precipitation is above $1300 \mathrm{~mm}$.

Once collected, the ticks were killed by freezing, counted, grouped according to their developmental stage, and identified according to morphological features [35, 36]. They were then stored at $-80^{\circ} \mathrm{C}$ until molecular analysis.

From November 2015 to January 2017, a spleen sample was also collected from red foxes ( $V$. vulpes) culled during sport hunting or population control programs and assigned to Istituto Zooprofilattico Sperimentale delle Venezie for the surveillance of zoonotic agents. Spleens were collected in 25 municipalities of the same province, with an altitude ranging from 263 to 1229 masl (Fig. 1), and were kept frozen at $-20{ }^{\circ} \mathrm{C}$ until testing.

\section{Molecular analysis}

Nucleic acids were extracted from the spleen of each fox, from adult ticks, pooled larvae (maximum 20 specimens) and pooled nymphs (maximum 10 specimens). Larvae were collected and screened for TBPs in 2011 only, due to their low infection rates and to budget optimization. In the following years, only 15 larvae detached from collectors were included in the study.

DNA was extracted from I. ricinus tick samples using the All Prep DNA/RNA mini Kit (Qiagen, Valencia, CA, USA), according to the manufacturer's instructions, and then kept frozen at $-80{ }^{\circ} \mathrm{C}$. DNA was extracted from spleen samples using DNeasy Blood \& Tissue Kit (Qiagen), according to the manufacturer's instructions, and stored at a temperature of $-20{ }^{\circ} \mathrm{C}$.

DNA from tick and spleen samples was amplified by conventional PCR or SYBR Green real-time PCR (rPCR) assays for Borrelia burgdorferi (s.l.), Rickettsia spp., Babesia spp., A. phagocytophilum and "Ca. N. mikurensis". The target genes, primers used and related references are listed in Table 1.
To ensure the effectiveness of DNA extraction, a PCR was applied targeting the $18 \mathrm{~S}$ rRNA gene internal control (Table 1) [37]. Negative (sterile water) and positive controls (DNA of B. burgdorferi (s.s.), R. helvetica, Ba. venatorum, $A$. phagocytophilum and "Ca. N. mikurensis") were included in each run.

PCR products were sequenced, in both directions, using the Big Dye Terminator v.3.1 cycle sequencing kit (Applied Biosystems, Foster City, CA, USA). The products of the sequencing reactions were purified using PERFORMA DTR Ultra 96-Well kit (Edge BioSystems, Gaithersburg, MD, USA), and sequenced in a 16capillary ABI PRISM 3130xl Genetic Analyzer (Applied Biosystems). Sequence data were assembled and edited with SeqScape software v2.5 (Applied Biosystems). The resulting sequences were aligned and compared with representative sequences available in GenBank.

RNA from tick samples was amplified by a specific real-time PCR (rRT-PCR) for TBE virus detection, as described elsewhere [38]. To ensure the effectiveness of RNA extraction, a real-time PCR targeting the $16 \mathrm{~S}$ rRNA gene of Ixodes spp. was applied [38] (Table 1).

\section{Statistical analysis}

For individual samples (adult ticks and foxes), the infection rate (IR) was calculated as the number of positive ticks/examined specimens. For pooled samples, the IR was calculated as the number of positive pools/total ticks examined in the pools (i.e. the minimum infection rate; https://tinyurl.com/y8uuopc6). Co-infections could not be estimated for pooled samples.

The significance of IR differences according to developmental stage and year of collection was tested using the Chi-square test $\left(\chi^{2}\right)$ or Fisher's exact test, where appropriate.

Data and tests were managed by SPSS software for Windows, v.13.0 (SPSS Inc., Chicago, IL, USA). Maps were produced using Qgis 2.14.18-Essen (2017, http,// https://qgis.org/it/site//) and graphs drawn up using

Table 1 Target pathogens, molecular method, target genes and primers used in this study

\begin{tabular}{|c|c|c|c|c|c|}
\hline Target & Method & Gene & Primer & Amplicon size (bp) & Reference \\
\hline B. burgdorferi (s.l.) & Traditional PCR & Flagellin & FLA1; FLA2 & 482 & [51] \\
\hline "Candidatus N. mikurensis" & Traditional PCR & groEL & $\begin{array}{l}\text { NM-350s (5'-GTG TAA TGA CAA AGT } \\
\text { TGG TGA TGG-3'); NM-1152as }\end{array}$ & 802 & This study; [52] \\
\hline A. phagocytophilum & SYBR green rPCR & msp2 & msp2-3f ; msp2-3r & 334 & [53] \\
\hline Rickettsia spp. & SYBR green $r P C R$ & $O m p B$ & rompB OFm; rompB ORm & 489 & [54] \\
\hline Babesia spp. & SYBR green rPCR & 185 rRNA & $\mathrm{BJ} 1 ; \mathrm{BN} 2$ & $411-452$ & [55] \\
\hline DNA extraction control & Traditional PCR & 185 rRNA & 18SU; 18SD & 488 & [37] \\
\hline TBE virus & TaqMan rRT-PCR & 3' non-coding region & F-TBE 1; R-TBE 1 TBE-Probe-WT & 67 & [38] \\
\hline RNA extraction control & TaqMan rRT-PCR & 165 rRNA & F-16s|xodes; R-16s|xodes; 16s-Ixodes-Probe & 97 & [38] \\
\hline
\end{tabular}


Tableau desktop v.10.4.0 Professional Edition` 2017 (Tableau Software Inc., Seattle, WA, USA).

\section{Results}

In the six years of monitoring, 2578 Ixodes ricinus ticks were collected and screened for TBPs. No other tick species were found in the study area. A total of 565 DNA/ RNA extracts were obtained from 264 adults, 24 pools of larvae $(n=330)$, and 277 pools of nymphs $(n=1984)$ (see Additional file 1: Table S1).

Overall, nine different pathogens were found to be circulating in the province, vectored by I. ricinus nymphs and adults: Rickettsia helvetica (3.69\%); R. monacensis (0.49\%); four species of Borrelia burgdorferi (s.l.) [B. afzelii (1.51\%); B. burgdorferi (s.s.) (1.25\%); B. garinii (0.18\%); and B. valaisiana (0.18\%)]; Anaplasma phagocytophilum (3.29\%), "Ca. Neoehrlichia mikurensis" (1.73\%), and Babesia venatorum (0.04\%) (Table 2). Larvae were collected and screened in the first year only $(n=$ $315)$ and two pools $(0.6 \%)$ were positive for $R$. helvetica. In the following years, 15 larvae were detached by forest rangers during sampling and two were found positive for $R$. helvetica and "Ca. mikurensis", respectively. Tick-borne encephalitis virus was not found in ticks even though human cases do regularly occur in the area.

The rate of infection in ticks varied widely according to tick developmental stage, site and year of collection (Table 3, Additional file 2: Figure S1 and Additional file 3: Figure S2). As expected, adults were more infected, with $27.6 \%$ harboring at least one pathogen, followed by nymphs $(7.3 \%)\left(\chi^{2}=109.780, d f=1, P=0.0001\right)$. Four adults $(0.7 \%)$ were co-infected with two pathogens each, i.e. one tick harbored B. burgdorferi (s.s.) + A. phagocytophilum, one tick $R$. helvetica $+B$. afzelii, one tick $R$. helvetica + A. phagocytophilum and one tick $R$. monacensis + A. phagocytophilum.

Pathogens with an IR above 1\% were recorded every year (Table 2). Borrelia burgdorferi (s.s.) was detected only in 2011 and 2012, B. garinii in 2011 and 2015, B. valaisiana from 2014 to 2016, and Ba. venatorum only in 2016.

The overall IR in nymphs was stable over the years, ranging between $6.1-8.5 \%\left(\chi^{2}=3.329, d f=1, P=0.6494\right)$, while adults showed large IR variability, with a significantly higher IR in 2011 (47.1\%; $\chi^{2}=20.4, d f=5, P=$ $0.0010)$ compared to the following years, when the IR ranged, but not significantly so $\left(\chi^{2}=2.813, d f=4, P=\right.$ 0.5896 ), from 11.8 to $29.4 \%$ (Table 3 ).

Specifically, in the five permanent sites the IRs in nymphs and adult ticks ranged as follows by species or pathogen complexes: Rickettsia spp. between 2.0-6.3\%; B. burgdorferi (s.l.) between 0.4-4.9\%, A. phagocytophilum between $0.4-6.1 \%$, and " $C a$. N. mikurensis" between 0-3.3\% (Additional file 2: Figure S1).

The pattern of IRs of TBPs across the years, in nymphs and adults, in the five permanent sites varied greatly (Additional file 3: Figure S2) among the different sites and also within the same site.

Concerning fox samples, a total of 97 foxes culled in Belluno Province were assigned to our laboratories: 70 from November 2015 to March 2016 and 27 from September 2016 to January 2017. None of the pathogens searched for in ticks was found in the foxes, while 52 foxes (54\%) tested positive for Babesia cf. microti (syns. Babesia microti-like, "Theileria annae", "Babesia annae", "Babesia vulpes"). The sequences obtained from all 52 positive samples were identical to each other. Three representative sequences (one per year) were submitted to GenBank

Table 2 Species and infection rates (\%) of pathogens found in 2248 Ixodes ricinus nymphs and adults collected from 2011 to 2016 , and sites positive for each pathogen by year of collection

\begin{tabular}{|c|c|c|c|c|c|c|c|c|c|}
\hline \multirow[t]{2}{*}{ Species } & \multirow{2}{*}{$\begin{array}{l}\text { No. of } \\
\text { infected ticks }\end{array}$} & \multirow[t]{2}{*}{$\%$} & \multirow[t]{2}{*}{$95 \% \mathrm{Cl}$} & \multicolumn{6}{|c|}{ Positive sites ( $n=$ total sites monitored) } \\
\hline & & & & $\begin{array}{l}2011 \\
(n=5)\end{array}$ & $\begin{array}{l}2012 \\
(n=13)\end{array}$ & $\begin{array}{l}2013 \\
(n=14)\end{array}$ & $\begin{array}{l}2014 \\
(n=14)\end{array}$ & $\begin{array}{l}2015 \\
(n=12)\end{array}$ & $\begin{array}{l}2016 \\
(n=8)\end{array}$ \\
\hline Rickettsia spp. & 91 & 4.05 & $3.23-4.86$ & 2 & 7 & 6 & 6 & 4 & 5 \\
\hline Rickettsia helvetica & 83 & 3.69 & $2.91-4.47$ & 2 & 6 & 6 & 4 & 4 & 5 \\
\hline Anaplasma phagocytophilum & 74 & 3.29 & $2.55-4.03$ & 2 & 4 & 4 & 5 & 4 & 1 \\
\hline Borrelia burgdorferi (s.l.) & 70 & 3.11 & $2.40-3.83$ & 4 & 3 & 5 & 1 & 7 & 5 \\
\hline "Ca. Neoehrlichia mikurensis" & 39 & 1.73 & $1.20-2.27$ & 4 & 3 & 3 & 4 & 3 & - \\
\hline Borrelia afzelii & 34 & 1.51 & $1.01-2.02$ & 2 & 3 & 5 & - & 6 & 4 \\
\hline Borrelia burgdorferi (s.s.) & 28 & 1.25 & $0.79-1.70$ & 3 & 1 & - & - & - & - \\
\hline Rickettsia monacensis & 11 & 0.49 & $0.20-0.78$ & 1 & 3 & - & 3 & - & 1 \\
\hline Borrelia garinii & 4 & 0.18 & $0.004-0.352$ & 1 & - & - & - & 2 & - \\
\hline Borrelia valaisiana & 4 & 0.18 & $0.004-0.352$ & - & - & - & 1 & 1 & 2 \\
\hline Babesia venatorum & 1 & 0.04 & $0.000-0.132$ & - & - & - & - & - & 1 \\
\hline
\end{tabular}


Table 3 Number of nymphs and adult ticks collected and infection rates (\%) of tick-borne pathogens according to developmental stage and year of collection

\begin{tabular}{|c|c|c|c|c|c|c|}
\hline \multirow[t]{2}{*}{ Year } & \multicolumn{2}{|l|}{ Nymphs } & \multicolumn{2}{|l|}{ Adults } & \multicolumn{2}{|l|}{ Total } \\
\hline & positive/tested & $\%(95 \% \mathrm{Cl})$ & positive/ tested & $\%(95 \% \mathrm{Cl})$ & positive/ tested & $\%(95 \% \mathrm{Cl})$ \\
\hline 2011 & $39 / 475$ & $8.2(5.74-10.6)$ & $33 / 70$ & $47.1(35.45-58.84)$ & $71 / 545$ & $13.0(10.20-15.85$ \\
\hline 2012 & $27 / 443$ & $6.1(3.87-8.32)$ & $17 / 80$ & $21.3(12.29-30.21)$ & $44 / 523$ & $8.4(6.03-10.79)$ \\
\hline 2013 & $18 / 292$ & $6.2(3.41-8.92)$ & $7 / 40$ & $17.5(5.72-29.28)$ & $25 / 332$ & $7.5(4.69-10.37)$ \\
\hline 2014 & $17 / 201$ & $8.5(4.61-12.30)$ & $10 / 34$ & $29.4(14.10-44.73)$ & $27 / 2354$ & $11.5(7.41-15.57)$ \\
\hline 2015 & $28 / 330$ & $8.5(5.48-11.49)$ & $2 / 17$ & $11.8(0.00-27.08)$ & $30 / 347$ & $8.6(5.69-11.60)$ \\
\hline 2016 & $16 / 243$ & $6.6(3.47-9.70)$ & $4 / 23$ & $17.4(1.90-32.88)$ & $20 / 266$ & $7.5(4.35-10.69)$ \\
\hline Total & $145 / 1984$ & $7.3(6.16-8.45)$ & $73 / 264$ & $27.6(22.26-33.05)$ & $218 / 2248$ & $9.7(8.47-10.92)$ \\
\hline
\end{tabular}

(accession numbers MG451837-MG451839). The IR rate was similar for foxes assigned in the periods 2015-2016 and 2016-2017 (50 vs 63\%) $\left(\chi^{2}=0.847, d f=1, P=0.3574\right)$.

Babesia cf. microti was found in all but four municipalities (Fig. 2).

\section{Discussion}

The results of this study confirmed that annual monitoring of Ixodes ricinus is a good surveillance method for zoonotic TBPs in the Province of Belluno. Protracted monitoring also provided information on rare pathogens and highlighted spatial-temporal fluctuations in tick populations, testifying to the focal nature of TBP lifecycles, which are in turn linked to variations in reservoir density and amplifying hosts [39]. Tick-borne encephalitis virus, known to affect humans in the province [25], remained undetected. This is not surprising as tick-borne encephalitis virus is restricted to distinct, sometimes very small foci all over Europe [40]. For this virus, notification of human cases and serological surveys on both domestic grazing animals and population groups at risk of infection remain the most informative systems [41].

Our results also showed that monitoring zoonotic TBPs in the specific context of northeastern Italy cannot be based on the currently available foxes as sentinel animals.

The infection rate of TBPs in red foxes is correlated with tick species and abundance in the environment, and with the infection rate of pathogens in ticks [30, 32, 42]. In previous European studies, blood or spleen samples of the red fox were found positive for several TBPs, namely A. phagocytophilum, B. canis, Bartonella rochalimae, B. burgdorferi, "Ca. Neoehrlichia sp.", Coxiella burnetii, Hepatozoon canis and Ehrlichia canis (Table 4).

Variable prevalences of $A$. phagocytophilum have been found in foxes around Europe, especially in central eastern European countries [30, 31, 43], where I. ricinus meets all the criteria to be a very efficient vector [44]. Interestingly, two surveys on TBPs in foxes performed eight years apart in the same province in central Italy, produced contrasting results for the prevalence of $A$. phagocytophilum, which fell from $16.6 \%$ in $2007 / 2008$ [29] to $0.65 \%$ in $2015 / 2016$ [32]. Between November 2013 and March 2015, a similar low prevalence (0.6\%) was also found in Austria [33], a country bordering northern Italy. Nevertheless it is difficult to interpret these results due to the paucity of data on fox abundance and density. In the case of Belluno Province, we could infer a maximum possible TBP prevalence of $3.03 \%$ in foxes, based on 97 sampled animals testing negative and on an estimated density of 3.38 foxes $/ \mathrm{km}^{2}$ [45]. However, this estimate of abundance can vary during the year according to fox ecology and can differ even on a small geographical scale, depending on different factors, such as food availability. In our case, a density of 3.38 foxes $/ \mathrm{km}^{2}$ was estimated in the southern countryside of Belluno Province, and could be misleading when considering the Alpine part of the territory.

Although a higher sample size would have increased the chance of finding positive foxes, the implementation of fox sampling was out of the scope of our study, which was to search for an alternative, low cost system of monitoring zoonotic TBPs, considering the current numbers of animals already sent to our laboratories.

The only TBP detected in the foxes examined here was Babesia cf. microti. More than $50 \%$ of foxes harbored this protozoan, in keeping with other European countries where prevalences of up to $69 \%$ have been reported (Table 4). The high prevalence of Babesia cf. microti in foxes and its absence in ticks strongly suggest that $I$. ricinus is not the vector of this pathogen. Accordingly, this protozoan is also present in countries where $I$. ricinus is absent, such as North America and Israel [46]. Ixodes hexagonus has been claimed to be a possible vector [47] and DNA of B. microti-like has been detected in all of the most common ticks infesting foxes in continental Europe [28], i.e. I. hexagonus, I. ricinus [48, 49], I. canisuga [48] and Dermacentor reticulatus [50]. The presence 


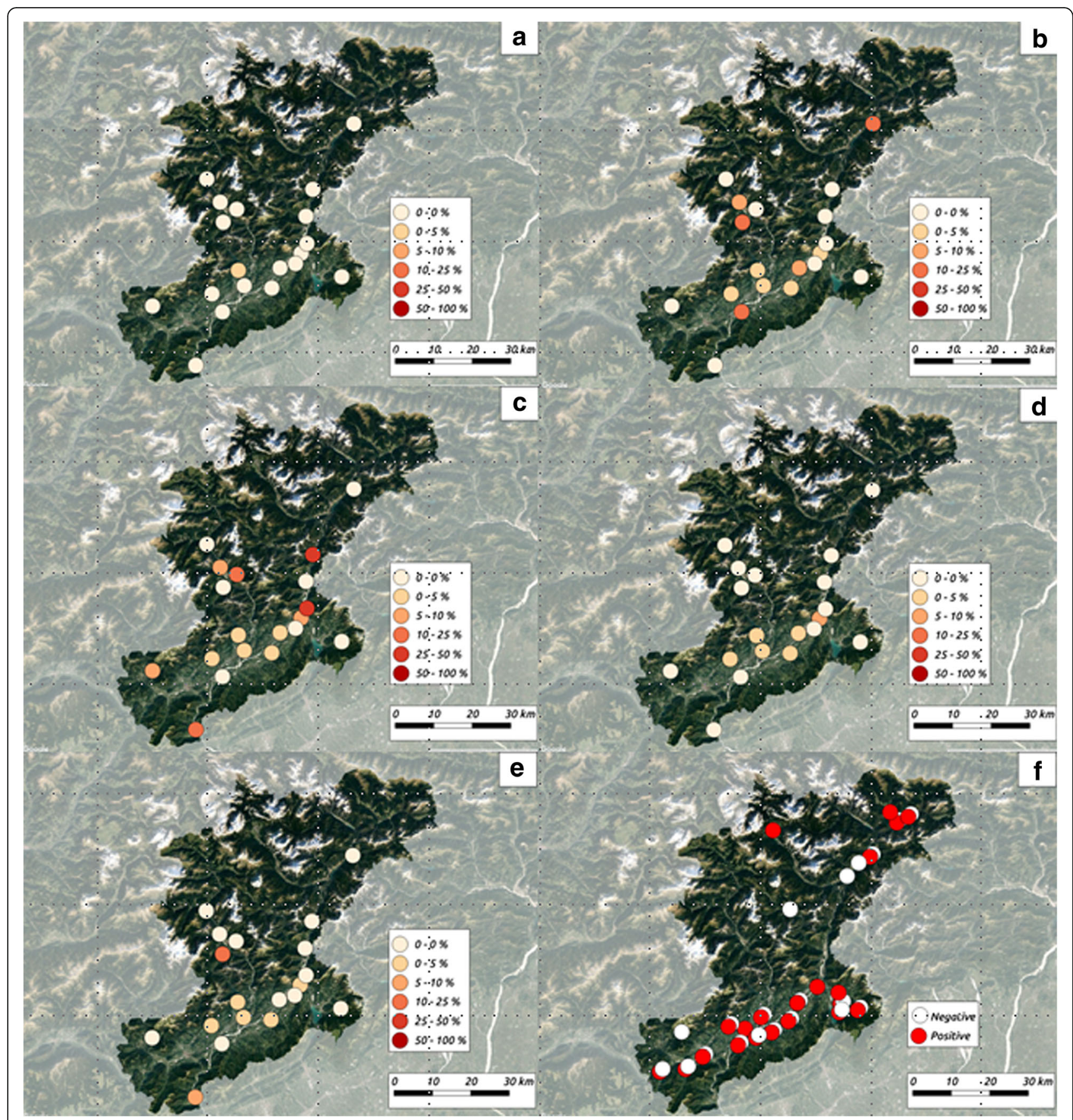

Fig. 2 Positive municipalities and range of infection rates for tick-borne pathogens found in ticks (a-e) and red foxes (f). a Babesia venatorum, $\mathbf{b}$ Borrelia burgdorferi complex, c Rickettsia spp., d Anaplasma phagocytophilum, e "Candidatus Neoehrlichia mikurensis", f Babesia cf. microti

of nucleic acids of pathogens in hematophagous arthropods is, however, a common finding and may not be related to their vectorial status. Other mechanisms of transmission are likely involved in the maintenance in nature of Babesia cf. microti, e.g. through the ingestion of infected ticks, as in the case of $H$. canis, another protozoan found at high prevalence in foxes
(Table 4), or by vertical transmission, as for other $\mathrm{Ba}$ besia species [46].

\section{Conclusions}

In areas endemic for vector-borne diseases, surveillance programmes are implemented to detect pathogens and define their spread. In the specific epidemiological 
Table 4 Tick-borne pathogen species and their prevalence (\%) in red foxes (Vulpes vulpes) in European countries

\begin{tabular}{|c|c|c|c|c|}
\hline Pathogens & Foxes tested & $\%$ & Country & Reference \\
\hline \multirow[t]{8}{*}{ A. phagocytophilum } & 506 & 0.6 & Austria & [33] \\
\hline & 25 & 4.0 & Czech Republic & [56] \\
\hline & 415 & 12.5 & Hungary & [30] \\
\hline & 122 & 8.2 & Germany & [43] \\
\hline & 150 & 16.6 & Italy & [29] \\
\hline & 153 & 0.65 & Italy & [32] \\
\hline & 353 & 2.5 & Romania & [31] \\
\hline & 162 & 3.0 & Switzerland & [57] \\
\hline \multirow[t]{12}{*}{ Babesia cf. microti } & 36 & 50.0 & Austria & [58] \\
\hline & $351-506$ & $50.7-25.7^{b}$ & Austria & [33] \\
\hline & 191 & 5.0 & Croatia & [59] \\
\hline & 121 & 46.5 & Germany & [48] \\
\hline & 195 & 47.5 & Germany & [60] \\
\hline & 316 & 14.6 & Great Britain & [61] \\
\hline & 404 & 20.0 & Hungary & [62] \\
\hline & 153 & 22.9 & Italy & [32] \\
\hline & 78 & 37.2 & Italy & [63] \\
\hline & 180 & 59.0 & Italy & [64] \\
\hline & 91 & 69.2 & Portugal & [65] \\
\hline & 300 & 9.7 & Slovakia & [66] \\
\hline \multirow[t]{2}{*}{ Babesia canis } & 351 & 0.3 & Austria & [33] \\
\hline & 91 & 1.1 & Portugal & [65] \\
\hline Bartonella rochalimae & 506 & 0.2 & Austria & [33] \\
\hline Borrelia burgdorferi (s.l.) & 353 & 1.4 & Romania & [31] \\
\hline \multirow[t]{2}{*}{ "Ca. Neoehrlichia sp." } & 164 & 0.6 & Austria & [67] \\
\hline & 506 & 0.4 & Austria & [33] \\
\hline Coxiella burnetii & 153 & 1.96 & Italy & [32] \\
\hline \multirow[t]{4}{*}{ Ehrlichia canis } & 105 & 52.0 & Italy & [68] \\
\hline & 153 & 44.4 & Italy & [32] \\
\hline & 13 & 31.0 & Italy & [68] \\
\hline & 180 & 6.1 & Italy & [64] \\
\hline \multirow[t]{7}{*}{ Hepatozoon canis } & 36 & 58.3 & Austria & [58] \\
\hline & $351-506$ & $18.5-29.8^{b}$ & Austria & [33] \\
\hline & 191 & 23.0 & Croatia & [59] \\
\hline & 415 & 22.2 & Hungary & [30] \\
\hline & 153 & 49.0 & Italy & [32] \\
\hline & 78 & 53.8 & Italy & [63] \\
\hline & 119 & 13.4 & Italy & [69] \\
\hline Rickettsia helvetica & 162 & 1.0 & Switzerland & [57] \\
\hline Rickettsia spp. & 180 & 5.0 & Italy & [64] \\
\hline
\end{tabular}

aSyns. B. microti-like, "Theileria annae", "B. annae", "B. vulpes"

$\mathrm{b}_{\mathrm{In}}$ blood and spleen of foxes, respectively 
context of northeastern Italy, and with the exception of tick-borne encephalitis virus, the molecular screening of TBPs in vector ticks remains a more efficient system than the screening of foxes as sentinel animals. The screening of foxes confirmed instead that Babesia cf. microti is endemic in northern Italy, as in many other European countries. Identification of the tick species vectoring the pathogen and the presence of alternative mechanisms of transmission are the next research tasks to be conducted on this protozoan.

\section{Additional files}

Additional file 1: Table S1. Ticks collected in 2011-2016 organized in pools, data of sites and results of molecular screening. (XLS $172 \mathrm{~kb}$ )

Additional file 2: Figure S1. Overall infection rates (IR) of tick-borne pathogens found in Ixodes ricinus ticks in the 5 permanent sites monitored in 2011-2016. Abbreviations: Apha, Anaplasma phagocytophilum; Bbs.l. Borrelia burgdorferi (sensu lato) complex; Bafz, Borrelia afzelii; Bbs.s., Borrelia burgdorferi (sensu stricto); Bval, Borrelia valaisiana; CNmi, "Candidatus Neoehrlichia mikurensis"; Rhel, Richettsia helvetica; Rmon, Rickettsia monacensis. (TIFF 29 kb)

Additional file 3: Figure S2. Pattern of tick-borne pathogens found in Ixodes ricinus in the five permanent sites according to year of sampling. Abbreviations: Apha, Anaplasma pagocytophilum; Bbs.l., Borrelia burgdorferi (sensu lato) complex; Bafz, Borrelia afzelii; Bbs.s., Borrelia burgdorferi (sensu stricto); Bval, Borrelia valaisiana; CNmi, "Candidatus Neoehrlichia mikurensis"; Rhel, Richettsia helvetica; Rmon, Rickettsia monacensis. (TIFF 161 kb)

\section{Abbreviations}

masl: meters above sea level; IR: infection rate; TBP: tick-borne pathogen; PCR: polymerase chain reaction

\section{Acknowledgements}

The authors wish to thank Stefania Cazzin for her technical help, the forestry rangers and all personnel who contributed to the collection of ticks and foxes, and Alessio Rainato for his technical help in building maps and graphs. We also thank Joanne Fleming for her English revision of the text. The publication of this paper has been sponsored by Bayer Animal Health in the framework of the 13th CVBD World Forum Symposium.

\section{Funding}

The study was partially funded by the Veneto Regional Government, Italy.

\section{Availability of data and materials}

Data supporting the conclusions of this article are included within the article and its additional files. Raw data of the collected ticks and sites, pools and molecular results are provided in Additional file 1. Representative sequences were submitted to the GenBank database under the accession numbers MG451837-MG451839.

\section{Authors' contributions}

GC, FM, FS and MS conceived the study. SR, GDR and GC wrote the paper. FM, SC, PD performed the tick collection and FM and SC the identification. CC and FO collected the fox samples. SR, EP and GDR performed the molecular tests. All authors contributed to the final version of the manuscript. All authors read and approved the final manuscript.

\section{Ethics approval and consent to participate}

Not applicable.

\section{Consent for publication}

Not applicable.

\section{Competing interests}

The authors declare that they have no competing interest.

\section{Publisher's Note}

Springer Nature remains neutral with regard to jurisdictional claims in published maps and institutional affiliations.

\section{Author details}

${ }^{1}$ Istituto Zooprofilattico Sperimentale delle Venezie, Legnaro, Italy. ${ }^{2}$ Local Health Unit, ULSS1-Dolomiti, Belluno, Italy.

Received: 5 January 2018 Accepted: 16 February 2018

Published online: 20 March 2018

\section{References}

1. Rizzoli A, Rosà R, Mantelli B, Pecchioli E, Hauffe H, Tagliapietra V, et al. Ixodes ricinus, transmitted diseases and reservoirs. Parassitologia. 2004;46:119-22.

2. Cinco M, Banfi E, Trevisan G, Stanek G. Characterization of the first tick isolate of Borrelia burgdorferi from Italy. APMIS. 1989;97:381-2

3. Cacciapuoti B, Ciceroni L, Ciarrocchi S, Khoury C, Simeoni J. Genetic and phenotypic characterization of Borrelia burgdorferi strains isolated from Ixodes ricinus ticks in the Province of Bolzano, Italy. New Microbiol. 1995;18:169-81.

4. Cinco M, Padovan D, Murgia R, Maroli M, Frusteri L, Heldtander M, et al. Coexistence of Ehrlichia phagocytophila and Borrelia burgdorferi sensu lato in Ixodes ricinus ticks from Italy as determined by 165 rRNA gene sequencing. J Clin Microbiol. 1997;35:3365-6.

5. Cinco M, Padovan D, Murgia R, Poldini L, Frusteri L, Van De Pol I, et al. Rate of infection of Ixodes ricinus ticks with Borrelia burgdorferi sensu stricto, Borrelia garinii, Borrelia afzelii and group VS116 in an endemic focus of Lyme disease in Italy. Eur J Clin Microbiol Infect Dis. 1998;17:90-4.

6. Ciceroni L, Ciarrocchi S, Simeoni J. Antigenic and genomic analysis of a Borrelia burgdorferi sensu stricto strain isolated from Ixodes ricinus ticks in Alto Adige-South Tyrol, Italy. Eur J Epidemiol. 1998;14:511-7.

7. Cinco M, Padovan D, Murgia R, Heldtander M, Engvall EO. Detection of HGE agent-like Ehrlichia in Ixodes ricinus ticks in northern Italy by PCR. Wien Klin Wochenschr. 1998;110:898-900

8. Hudson PJ, Rizzoli A, Rosà R, Chemini C, Jones LD, Gould EA. Tick-borne encephalitis virus in northern Italy: molecular analysis, relationships with density and seasonal dynamics of Ixodes ricinus. Med Vet Entomol. 2001;15:304-13

9. Favia G, Cancrini G, Carfi A, Grazioli D, Lillini E, lori A. Molecular identification of Borrelia valaisiana and HGE-like Ehrlichia in Ixodes ricinus ticks sampled in north-eastern Italy: first report in Veneto region. Parassitologia. 2001:43:143-6.

10. Beninati T, Lo N, Noda H, Esposito F, Rizzoli A, Favia G, et al. First detection of spotted fever group rickettsiae in Ixodes ricinus from Italy. Emerg Infect Dis. 2002:8:983-6.

11. Piccolin G, Benedetti G, Doglioni C, Lorenzato C, Mancuso S, Papa N, et al. A study of the presence of B. burgdorferi, Anaplasma (previously Ehrlichia) phagocytophilum, Rickettsia, and Babesia in Ixodes ricinus collected within the Territory of Belluno, Italy. Vector-Borne Zoonotic Dis. 2006:6:24-31.

12. Mantelli B, Pecchioli E, Hauffe HC, Rosà R, Rizzoli A. Prevalence of Borrelia burgdorferi s.l. and Anaplasma phagocytophilum in the wood tick Ixodes ricinus in the Province of Trento, Italy. Eur J Clin Microbiol Infect Dis. 2006:25:737-9.

13. Floris R, Altobelli A, Boemo B, Mignozzi K, Cinco M. First detection of TBE virus sequences in Ixodes ricinus from Friuli Venezia Giulia (Italy). New Microbiol. 2006;29:147-50.

14. Pecchioli E, Hauffe H, Tagliapietra V, Bandi C, Genchi C, Rizzoli A. genospecies of Borrelia burgdorferi sensu lato in Ixodes ricinus ticks from the Autonomous Province of Trento, Italy. Int J Med Microbiol. 2007;297:53-9.

15. Floris R, Yurtman AN, Margoni EF, Mignozzi K, Boemo B, Altobelli A, et al. Detection and identification of Rickettsia species in the northeast of Italy. Vector-Borne Zoonotic Dis. 2008:8:777-82.

16. D'Agaro P, Martinelli E, Burgnich P, Nazzi F, Del Fabbro S, lob A, et al. Prevalence of tick-borne encephalitis virus in Ixodes ricinus from a novel endemic area of northeastern Italy. J Med Virol. 2009;81:309-16.

17. Carpi G, Bertolotti L, Rosati S, Rizzoli A. Prevalence and genetic variability of tick-borne encephalitis virus in host-seeking Ixodes ricinus in northern Italy. J Gen Virol. 2009:90:2877-83.

18. Cassini R, Bonoli C, Montarsi F, Tessarin C, Marcer F, Galuppi R. Detection of Babesia EU1 in Ixodes ricinus ticks in northern Italy. Vet Parasitol. 2010;171:151-4 
19. Capelli G, Ravagnan S, Montarsi F, Ciocchetta S, Cazzin S, Porcellato E, et al. Occurrence and identification of risk areas of Ixodes ricinus-borne pathogens: a cost-effectiveness analysis in north-eastern Italy. Parasit Vectors. 2012;5:61.

20. Baráková I, Derdáková M, Selyemová D, Chvostáč M, Špitalská E, Rosso F, et al. Tick-borne pathogens and their reservoir hosts in northern Italy. Ticks Tick Borne Dis. 2018;9(2):164-70.

21. Ciceroni L, Ciarrocchi S. Lyme disease in Italy, 1983-1996. New Microbiol. 1998;21:407-18.

22. Sanogo YO, Parola P, Shpynov S, Camicas JL, Brouqui P, Caruso G, et al. Genetic diversity of bacterial agents detected in ticks removed from asymptomatic patients in northeastern Italy. Ann N Y Acad Sci. 2003;990:182-90.

23. Brouqui P, Sanogo YO, Caruso G, Merola F, Raoult D. Candidatus Ehrlichia walkerii: a new Ehrlichia detected in Ixodes ricinus tick collected from asymptomatic humans in northern Italy. Ann N Y Acad Sci. 2003; 990:134-40

24. Koutaro M, Santos AS, Dumler JS, Brouqui P. Distribution of "Ehrlichia walkeri" in Ixodes ricinus (Acari: Ixodidae) from the northern part of Italy. J Med Entomol. 2005:42:82-5.

25. Rezza G, Farchi F, Pezzotti P, Ruscio M, Lo Presti A, Ciccozzi M, et al. Tickborne encephalitis in north-east Italy: a 14-year retrospective study, January 2000 to December 2013. Eurosurveillance. 2015;20:30034

26. Cinco M, Luzzati R, Mascioli M, Floris R, Brouqui P. Serological evidence of Rickettsia infections in forestry rangers in north-eastern Italy. Clin Microbiol Infect. 2006;12:493-5.

27. Ente Parco Nazionale delle Dolomiti Bellunesi. Dolomiti Bellunesi National Park. http://www.dolomitipark.ti/en/mammiferi.php. Accessed on 2 Nov 2017

28. Sándor AD, D’Amico G, Gherman CM, Dumitrache MO, Domșa C, Mihalca AD. Mesocarnivores and macroparasites: altitude and land use predict the ticks occurring on red foxes (Vulpes vulpes). Parasit Vectors. 2017;10:173.

29. Ebani W, Verin R, Fratini F, Poli A, Cerri D. Molecular survey of Anaplasma phagocytophilum and Ehrlichia canis in red foxes (Vulpes vulpes) from central Italy. J Wildl Dis. 2011:47:699-703.

30. Tolnai Z, Sréter-Lancz Z, Sréter T. Spatial distribution of Anaplasma phagocytophilum and Hepatozoon canis in red foxes (Vulpes vulpes) in Hungary. Ticks Tick Borne Dis. 2015;6:645-8.

31. Dumitrache MO, Matei IA, Ionică AM, Kalmár Z, D’Amico G, Sikó-Barabási S, et al. Molecular detection of Anaplasma phagocytophilum and Borrelia burgdorferi sensu lato genospecies in red foxes (Vulpes vulpes) from Romania. Parasit Vectors. 2015;8:514

32. Ebani W, Rocchigiani G, Nardoni S, Bertelloni F, Vasta V, Papini RA, et al. Molecular detection of tick-borne pathogens in wild red foxes (Vulpes vulpes) from central Italy. Acta Trop. 2017;172:197-200.

33. Hodžić A, Mrowietz N, Cézanne R, Bruckschwaiger P, Punz S, Habler VE, et al. Occurrence and diversity of arthropod-transmitted pathogens in red foxes (Vulpes vulpes) in western Austria, and possible vertical (transplacental) transmission of Hepatozoon canis. Parasitology. 2017;24:1-10.

34. Nazzi F, Martinelli E, Del Fabbro S, Bernardinelli I, Milani N, lob A, et al. Ticks and Lyme borreliosis in an alpine area in northeast Italy. Med. Vet. Entomol. 2010;24(3):220-6.

35. Manilla G, lori A. Illustrated key to the ticks of Italy. I. Larval stages of the species of the Ixodinae subfamily (Acari, Ixodoidea, Ixodidae). Parassitologia. 1992:34:83-95

36. Manilla G. Fauna d'Italia. Acari Ixodida. Bologna: Calderini Press; 1998.

37. Smith J, McElhinney LM, Heaton PR, Black EM, Lowings JP. Assessment of template quality by the incorporation of an internal control into a RT-PCR for the detection of rabies and rabies-related viruses. J Virol Methods. 2000;84:107-15.

38. Schwaiger M, Cassinotti P. Development of a quantitative real-time RT-PCR assay with internal control for the laboratory detection of tick-borne encephalitis virus (TBEV) RNA. J Clin Virol. 2003;27:136-45.

39. Bolzoni L, Rosà R, Cagnacci F, Rizzoli A. Effect of deer density on tick infestation of rodents and the hazard of tick-borne encephalitis. II: Population and infection models. Int J Parasitol. 2012:42:373-81.

40. Randolph SE. The shifting landscape of tick-borne zoonoses: tick-borne encephalitis and Lyme borreliosis in Europe. Philos Trans R Soc Lond B Biol Sci. 2001;356:1045-56.

41. Ergunay K, Tkachev S, Kozlova I, Růžek D. A review of methods for detecting tick-borne encephalitis virus infection in tick, animal, and human specimens. Vector-Borne Zoonotic Dis. 2016;16:4-12.

42. Santoro M, Veneziano V, D'Alessio N, Di Prisco F, Lucibelli MG, Borriello G, et al. Molecular survey of Ehrlichia canis and Coxiella burnetii infections in wild mammals of southern Italy. Parasitol Res. 2016;115:4427-31.
43. Hartwig V, von Loewenich FD, Schulze C, Straubinger RK, Daugschies A, Dyachenko V. Detection of Anaplasma phagocytophilum in red foxes (Vulpes vulpes) and raccoon dogs (Nyctereutes procyonoides) from Brandenburg, Germany. Ticks Tick Borne Dis. 2014:5:277-80.

44. Karbowiak G, Biernat B, Szewczyk T, Sytykiewicz H. The role of particular tick developmental stages in the circulation of tick-borne pathogens affecting humans in central Europe. 1. The general pattern. Ann Parasitol. 2015;61:221-8.

45. Obber F, Capello K, Mulatti P, Lorenzetto M, Vendrami S, Citterio CV. Exploring the use of red fox (Vulpes vulpes) counts during deer censuses as a tool to evaluate the fox population trend in the framework of disease surveillance. Hystrix. https://doi.org/10.4404/hystrix-00048-2018.

46. Baneth G, Florin-Christensen M, Cardoso L, Schnittger L. Reclassification of Theileria annae as Babesia vulpes sp. nov. Parasit Vectors. 2015;8:207.

47. Camacho AT, Pallas E, Gestal JJ, Guitián FJ, Olmeda AS, Telford SR, et al. Ixodes hexagonus is the main candidate as vector of Theileria annae in northwest Spain. Vet Parasitol. 2003;112:157-63.

48. Najm N-A, Meyer-Kayser E, Hoffmann L, Herb I, Fensterer V, Pfister K, et al. A molecular survey of Babesia spp. and Theileria spp. in red foxes (Vulpes vulpes) and their ticks from Thuringia, Germany. Ticks Tick Borne Dis. 2014;5:386-91.

49. Lledó L, Giménez-Pardo C, Domínguez-Peñafiel G, Sousa R, Gegúndez MI, Casado N, et al. Molecular detection of hemoprotozoa and Rickettsia species in arthropods collected from wild animals in the Burgos Province, Spain. Vector-Borne Zoonotic Dis. 2010;10:735-8.

50. Hodžić A, Zörer J, Duscher GG. Dermacentor reticulatus, a putative vector of Babesia cf. microti (syn. Theileria annae) piroplasm. Parasitol Res. 2017; 116:1075-7.

51. Skotarczak B, Wodecka B, Cichocka A. Coexistence DNA of Borrelia burgdorferi sensu lato and Babesia microti in Ixodes ricinus ticks from north-western Poland. Ann Agric Environ Med. 2002;9:25-8

52. Diniz PPVP, Schulz BS, Hartmann K, Breitschwerdt EB. "Candidatus Neoehrlichia mikurensis" infection in a dog from Germany. J Clin Microbiol. 2011;49:2059-62.

53. Massung RF, Slater KG. Comparison of PCR assays for detection of the agent of human granulocytic ehrlichiosis, Anaplasma phagocytophilum. J Clin Microbiol. 2003:41:717-22.

54. Veronesi F, Ravagnan S, Cerquetella M, Carli E, Olivieri E, Santoro A, et al. First detection of Cytauxzoon spp. infection in European wildcats (Felis silvestris silvestris) of Italy. Ticks Tick Borne Dis. 2016;7:853-8.

55. Casati S, Sager H, Gern L, Piffaretti J-C. Presence of potentially pathogenic Babesia sp. for human in Ixodes ricinus in Switzerland. Ann Agric Environ Med. 2006:13:65-70.

56. Hulinska D, Langrova K, Pejcoch M, Pavlasek I. Detection of Anaplasma phagocytophilum in animals by real-time polymerase chain reaction. APMIS. 2004:112:239-47.

57. Hofmann-Lehmann R, Wagmann N, Meli ML, Riond B, Novacco M, Joekel $D$, et al. Detection of "Candidatus Neoehrlichia mikurensis" and other Anaplasmataceae and Rickettsiaceae in Canidae in Switzerland and Mediterranean countries. Schweiz Arch Tierheilkd. 2016:158:691-700.

58. Duscher GG, Fuehrer H-P, Kübber-Heiss A. Fox on the run - molecular surveillance of fox blood and tissue for the occurrence of tick-borne pathogens in Austria. Parasit Vectors. 2014;7:521

59. Dezdek D, Vojta L, Curković S, Lipej Z, Mihaljević Z, Cvetnić Z, et al. Molecular detection of Theileria annae and Hepatozoon canis in foxes (Vulpes vulpes) in Croatia. Vet Parasitol. 2010:172:333-6.

60. Liesner JM, Krücken J, Schaper R, Pachnicke S, Kohn B, Müller E, et al. Vectorborne pathogens in dogs and red foxes from the federal state of Brandenburg Germany. Vet Parasitol. 2016;224:44-51.

61. Bartley PM, Hamilton C, Wilson C, Innes EA, Katzer F. Detection of Babesia annae DNA in lung exudate samples from red foxes (Vulpes vulpes) in Great Britain. Parasit Vectors. 2016;9:84

62. Farkas R, Takács N, Hornyák Á, Nachum-Biala Y, Hornok S, Baneth G. First report on Babesia cf. microti infection of red foxes (Vulpes vulpes) from Hungary. Parasit Vectors. 2015;8:55.

63. Rocchigiani G, Papini R, Vasta V, Nardoni S, Leoni A, Mancianti F. Molecular evidence of Babesia vulpes and Hepatozoon canis infections in red foxes (Vulpes vulpes) from the Province of Pisa (central Italy). Bari: Proceedings XXIX Congresso Nazionale della Società Italiana di Parassitologia (SOIPA); 2016

64. Torina A, Crucitti D, Di Pasquale C, Marino F, De Maria C, Tarantino V, et al. Molecular detection of tick-borne pathogens in sicilian wild animals. Roma: Proceedings XXIX Congresso Nazionale della Società Italiana di Parassitologia (SOIPA); 2014. p. 220. 
65. Cardoso L, Cortes HCE, Reis A, Rodrigues P, Simões M, Lopes AP, et al. Prevalence of Babesia microti-like infection in red foxes (Vulpes vulpes) from Portugal. Vet Parasitol. 2013;196:90-5.

66. Koneval M, Miterpáková M, Hurníková Z, Blaňarová L, Víchová B. Neglected intravascular pathogens, Babesia vulpes and haemotropic Mycoplasma spp. in European red fox (Vulpes vulpes) population. Vet Parasitol. 2017;243:176-82.

67. Hodžić A, Cézanne R, Duscher GG, Harl J, Glawischnig W, H-PH-P F. Candidatus Neoehrlichia sp. in an Austrian fox is distinct from Candidatus Neoehrlichia mikurensis, but closer related to "Candidatus Neoehrlichia lotoris". Parasit Vectors. 2015;8:539.

68. Torina A, Blanda V, Antoci F, Scimeca S, D'Agostino R, Scariano E, et al. A molecular survey of Anaplasma spp., Rickettsia spp., Ehrlichia canis and Babesia microti in foxes and fleas from Sicily. Transbound Emerg Dis. 2013;60:125-30

69. Gabrielli S, Kumlien S, Calderini P, Brozzi A, lori A, Cancrini G. The first report of Hepatozoon canis identified in Vulpes vulpes and ticks from Italy. VectorBorne Zoonotic Dis. 2010;10:855-9.

Submit your next manuscript to BioMed Central and we will help you at every step:

- We accept pre-submission inquiries

- Our selector tool helps you to find the most relevant journal

- We provide round the clock customer support

- Convenient online submission

- Thorough peer review

- Inclusion in PubMed and all major indexing services

- Maximum visibility for your research

Submit your manuscript at www.biomedcentral.com/submit 